\title{
Comparison of the Performance of Submerged Membrane Bioreactor (SMBR) and Submerged Membrane Adsorption Bioreactor (SMABR)
}

\author{
Wenshan Guo, Saravanamuthu Vigneswaran *, Huu-Hao Ngo, \\ Wen Xing, Pavan Goteti \\ Faculty of Engineering, University of technology, Sydney, \\ P.O. Box 123, Broadway, NSW 2007, Australia \\ * Correspondence author, tel: +61-2-9514-2641, fax: + 61-2-9514-2633, \\ E-mail: S.Vigneswaran@uts.edu.au
}

\begin{abstract}
This study focuses on comparing the performance of submerged membrane bioreactor (SMBR) and submerged membrane adsorption bioreactor (SMABR) over a period of 20 days at a hydraulic retention time (HRT) of 3.1 hours. The effects of PAC on critical flux and membrane fouling were also investigated. The SMABR exhibited better results in terms of mixed liquor suspended solids (MLSS) growth, DOC removal (over 96\%), COD removal (over 95\%), transmembrane pressure (TMP) and oxygen uptake rate. Nearly $100 \%$ of bacteria and $100 \%$ removals of total coliforms were removed in both systems. The addition of PAC could maintain the critical flux at a lower TMP value $(7.5 \mathrm{kPa})$, while irreversible fouling caused by PAC occurred when the filtration flux exceeded critical flux.
\end{abstract}

Keywords: Submerged membrane bioreactor; Oxygen uptake rate; Critical flux; Adsorption 


\section{Introduction}

The use of membrane filtration technology has been advancing in a rapid place in replacing the conventional water and wastewater treatment processes to produce high quality treated water. Among the membrane processes, membrane bioreactor (MBR) technology is becoming an innovative and promising option for wastewater treatment and reuse. MBR comprises of a suspended growth bioreactor and a filtration on porous membrane, which leads to the total retention of biomass (high microbial concentration) and improved biological reactor operation (high sludge ages) in the bioreactor (Lee et al., 2003). In MBR system design, the submerged membrane configuration can assist in significantly reducing power consumption.

Although MBR offers the effective separation of pollutants and persistence to high or shock loadings, membrane fouling is still an unavoidable obstacle. The occurrence of fouling affects the performance of the membrane either by deposition of a layer onto the membrane surface which introduces additional resistance to permeate flow, or by blockage or partial blockage of the pores which changes the effective pore size distribution (Field et al., 1995). The characteristics of activated sludge (AS) in MBR are one of the cardinal factors to membrane fouling. The sludge matrix within MBR is a mixed liquor of two main fractions: (i) biological flocs formed by a large range of living microorganisms, and (ii) supernatant containing soluble and colloidal compounds. Each element has its own physicochemical and biological properties affecting membrane fouling (Lee et al., 2003; Le Clech at al., 2003). Various attempts have been made to reduce the membrane fouling in submerged MBR (SMBR). Yamamoto et al. (1989) examined the influence of operational modes and found that intermittent suction greatly 
reduced membrane fouling compared to continuous suction. Lee at al. (2001) indicated that alum and natural zeolite addition to a SMBR not only reduced membrane fouling, but also increased the removal of COD. Furthermore, the association of SMBR and powdered activated carbon (PAC) became a promising unit process for advanced water treatment, because the addition of PAC as pretreatment to membrane processes (such as microfiltration (MF) or ultrafiltration (UF)) could achieve more dissolved organic carbon (DOC) and disinfection by-products (DBPs) removal and mitigate membrane fouling by reducing organic loading to membrane adsorbing organic matters (Kim et al., 2001; Clark and Heneghan, 1991). Tsai et al. (2005) summarized the advantages of PAC addition in MBR system, which indicated that PAC has adsorptive affinity for removal of biologically resistant compounds that may be toxic to the microbial community and it provides an excellent surface for the attachment of microorganisms (Ying and Weber, 1979; Pirbazari et al., 1990a). In SMBR, the entire treatment activity (such as adsorption/biodegradation, liquid-solid separation, and sludge accumulation and withdrawal) can be carried out in a single unit.

The bacterial activity during operation of MBR can be evaluated by measuring the oxygen consumption (by respirometric procedure). Nowadays, the oxygen demand measurement gains great interest because it is directly linked to the biological activity. Thus, respirometry is considered as an essential parameter for controlling AS process in MBR (Rodde-Pellegrin et al., 2002). It is well known that respirometry has the following advantages: (i) it can be used for those substrates that cannot be easily determined analytically, (ii) it is much more sensitive than the methods based on biomass growth or substrate removal, (iii) it is detectable even for substrate 
concentrations below $1 \mathrm{mg} / \mathrm{L}$, (iv) it determines the kinetic constants of mixed cultures without changing the qualitative and quantitative composition of the culture, and (v) it is simple and easy method (Pitter and Chudoba, 1990).

The objective of this study is to compare the performances of two MBR systems, namely SMBR alone and submerged membrane adsorption bioreactor (SMABR) in treating a synthetic secondary wastewater. Oxygen uptake rate (OUR) was used to measure the biological activities in both the bioreactors, including the suspended growth in SMBR and suspended/attached growth in SMABR. Dissolved organic carbon (DOC) removal, COD removal, mixed liquor suspended solids (MLSS), transmembrane pressure (TMP), total viable counts and total coliform counts were also investigated. After 20 days operation, critical flux (the critical flux is the flux below which there is no presence of TMP increase in resistance) experiments were conducted to examine the filtration flux stability in both the systems.

\section{Methods}

\subsection{Wastewater}

The experiments were conducted using a synthetic wastewater to avoid any fluctuation in the feed concentration and provide a continuous source of completely biodegradable organic pollutants. It was used to simulate high strength domestic wastewater (just after primary treatment process). The synthetic wastewater has DOC of 120-130 mg/L and COD of 320-350 mg/L (COD: N: P = 100:5:1). The composition of synthetic wastewater is given in Table 1 (Lee et al., 2003). $\mathrm{NaHCO}_{3}$ or $\mathrm{H}_{2} \mathrm{SO}_{4}$ were added to the wastewater to maintain a constant $\mathrm{pH}$ around 7. 
Table 1 Constituents of the Synthetic Wastewater

\subsection{SMBR and SMABR set-up}

SMBR and SMABR systems were operated at a constant permeate flux of $10 \mathrm{~L} / \mathrm{m}^{2} . \mathrm{h}$ under the same hydraulic retention time (HRT) of 3.1 hours. Each MBR consisted of an activated sludge bioreactor having an effective volume of 6 L. Initially, SMBR and SMABR were filled with sludge and acclimatized to synthetic wastewater for 12 days. The source of the seeding sludge was from Castle Hill Wastewater Treatment Plant in Sydney. The MLSS concentration of the activated sludge was $1.25 \mathrm{~g} / \mathrm{L}$. Synthetic wastewater was then added gradually during the acclimatization time to support the microbial growth in both the MBR systems. In SMABR system, a predetermined amount of PAC $(5 \mathrm{~g} / \mathrm{L})$ was added into the reactor at the beginning of the acclimatization period to adsorb the dissolved organic substances. The PAC amount was predetermined according to the previous study of the authors (Guo et al., 2005). The PAC (80\% min finer than 75 micron) used was wood based carbon with a surface area of $882 \mathrm{~m}^{2} / \mathrm{g}$ and a mean pore diameter of $30.61 \AA$. There was no further addition of PAC during the experimental period.

A polyethylene hollow fiber membrane module was used with the pore size of 0.1 $\mu \mathrm{m}$ and surface area of $0.195 \mathrm{~m}^{2}$. The schematic diagram of the submerged hollow fiber microfiltration system is shown in Fig. 1. Synthetic wastewater was pumped into the reactor using a feeding pump to control the feed rate while the effluent flow rate was controlled by a suction pump. Level sensor was used to control the wastewater volume in the reactor. A pressure gauge was used to measure the transmembrane pressure (TMP) 
and a soaker hose air diffuser was used to maintain a high air flow rate $(9 \mathrm{~L} / \mathrm{min}$ or 2.77 $\mathrm{m}^{3} / \mathrm{m}^{2}$ (membrane area).h). The bubbling of air has three functions in the systems: (i) sweeping the membrane surface, (ii) mixing the PAC in SMABR and (iii) supplying oxygen to facilitate the biological degradation organics during the long term operation of MBR. For physical cleaning of membranes, filtrate backwash was used every 1 hour for $1 \mathrm{~min}$ duration at a backwash rate of $30 \mathrm{~L} / \mathrm{m}^{2} . \mathrm{h}$.

Fig. 1. Experimental set-up of SMBR

\subsection{Analysis}

YSI 5300 Biological Oxygen Monitor was used to measure oxygen uptake rate due to its useful tool for measuring samples including respiration, oxidative activity, and cellular metabolism studies. The oxygen consumption measurement can be achieved through use of oxygen electrode with oxygen permeable Teflon membrane. Voltage generated from the reaction is proportional to the oxygen concentration of the sample and produces oxygen uptake or evolution curves in 2 to 15 minutes. During the acclimatization, the wastewater withdrawn from the aeration tank at different periods was monitored. DOC of the influent and effluent was measured using the Analytikjena Multi N/C 2000. For measuring MLSS, three samples were taken each time and the average values were then calculated. Total viable counts and total coliform counts were carried out using spread plate technique on nutrient agar and MacConkey agars as media respectively. All samples were diluted using $0.1 \%$ bacteriological peptone water. Nutrient agar, MacConkey agar and bacteriological peptone were obtained from $\mathrm{OXOID}^{\circledR}$. 


\section{Results and Discussion}

\subsection{Comparison of MLSS growth}

The average concentrations of MLSS in the two systems were investigated. After 12 days of acclimatization, SMBR and SMABR started with the MLSS concentration of $2.58 \mathrm{~g} / \mathrm{L}$ and $1.81 \mathrm{~g} / \mathrm{L}$ respectively. The growth of MLSS in SMBR was steady and gradual, whereas a significantly higher growth was observed in SMABR system due to the increase of adsorption surface area made available through the incorporation of PAC. The average concentrations of MLSS in SMABR remained constant (around $10 \mathrm{~g} / \mathrm{L}$ ) after a 10 day-operation.

\subsection{Comparison of organic removal}

DOC and COD removal efficiencies were measured during the 20 days of operation, which are shown in Fig. 2. The results indicated that both systems achieved excellent DOC and COD removals of over $95 \%$ and $94 \%$ respectively. SMABR had slightly higher DOC and COD removal efficiencies as compared to SMBR (reaching up to $99 \%$ DOC removal and $100 \%$ COD removal occasionally). This is due to PAC had the simultaneous functions of biodegradation by attached microorganisms on its surface as well as adsorption to improve the DOC and COD removal efficiencies. During the operation of SMABR, bioreaction took place due to the growth of the biomass supported by PAC. The adsorbed organics on the PAC were biodegraded with time by the biomass, which hence created sites for further adsorption of organics on the PAC. Since the simultaneous activity of biodegradation and adsorption on PAC attained at its peak after 5 days, the DOC and COD removal efficiencies decreased slightly from day 6

to 12 . However, after the $13^{\text {th }}$ day of operation, the DOC and COD removal restored 
again as a permeable activated sludge layer was formed on some membrane fibers. The later was made through visual observation.

Fig. 2. DOC and COD profile of SMBR and SMABR systems (filtration flux $=10 \mathrm{~L} / \mathrm{m}^{2} . \mathrm{h}$; PAC dose $=5 \mathrm{~g} / \mathrm{L} ;$ backwash rate $=30 \mathrm{~L} / \mathrm{m}^{2} . h ;$ backwash $=1$ minute every 1 hour; HRT $=3.1)$

In this study, SMABR and SMBR performance had a marginal difference in terms of the organic removals because the synthetic wastewater used in this study was completely biodegradable organic pollutants. The advantage of SMABR is to remove persistent organic compounds. SMABR showed much higher organic removal efficiency than SMBR when persistent organic compounds were present in the wastewater. Another study conducted by the authors showed the capability of SMABR in removing persistent organic matters (Guo et al., 2005).

\subsection{Comparison of TMP}

In any membrane bioreactor, the TMP generally increases with the operational time. Usually, it can only be reduced by membrane cleaning. In the field works, SMBR together with automation backwash control are normally used to minimize the membrane fouling thus to extend the operation period of the MBR system. PAC plays a significant role in fouling reduction as PAC adsorbs a part of the organic matter. The variation of TMP values were measured during the operation of both SMBR and SMABR systems. The TMP in both cases increased slightly during the 20-day of operation (e.g. $9 \mathrm{kPa}$ and $7.5 \mathrm{kPa}$ of TMP developed in SMBR and SMABR respectively). The SMABR system had lower TMP development compared to SMBR system. This is due to the direct adsorption of dissolved organic matters onto PAC. Thus, PAC can mitigate the membrane fouling. 


\subsection{Comparison of Oxygen uptake rate (OUR)}

OUR was used to study the dissolved oxygen (DO) consumption rates in both SMBR and SMABR systems. This relates to the microbial activity at different periods of experiment. Figs. 3 and 4 present the DO variation of the mixed liquor from the aeration tank of both the systems. In SMBR system, the OUR had a lower value during the first 3 days (55\% on the first day and $72 \%$ on the third day). Moreover, the OUR reached the equilibrium within 16 and 28 minutes with the mixed liquor taken after 1 and 3 days respectively. After that, the OUR of SMBR system was over $94 \%$ and equilibrated within 14 minutes. On the other hand, the OUR in SMABR system had better performance from the initial stage of the experiment (also reached the equilibrium within 14 minutes), which meant that there were more microbial substances in SMABR system. The same conclusions were drawn from MLSS and DOC removal efficiencies.

Fig. 3. OUR variation of the mixed liquor in SMBR system

Fig. 4. OUR variation of the mixed liquor in SMABR system

\subsection{Comparison of total viable counts and total coliform counts}

A quantitative microbiological analysis was carried out with influent, effluent and mixed liquor of SMBR and SMABR on a regular basis. In order to estimate the number of viable bacteria in these samples, viable counts were carried out with the spread plate technique using nutrient agar as medium. Uniform increase in number of viable bacteria was observed in the mixed liquor of both the systems (Table 2). This may be due to the fact that the composition of synthetic wastewater used in these experiments was very rich in nutritional sources such as glucose and yeast extract. In SMBR, the viable 
numbers increased rapidly and reached a stationary phase in 10 days (around $6 \times 10^{2}$ $\mathrm{cfu} / \mathrm{ml}$ ). On the other hand, higher degree of growth was noticed in SMABR and bacterial numbers increased rapidly from $3.5 \times 10^{2}$ to $2.24 \times 10^{4} \mathrm{cfu} / \mathrm{ml}$ during the first 15-day of operation. Adsorption of bacteria on to PAC particles must have contributed to this high numbers. In reality, the bacterial amount in this sample should even be more. The underestimation was due to the difficulty in detaching them from PAC particles.

In order to test the microbiological quality of treated wastewater, viable counts were carried out in both influent and effluent samples. Total coliform counts were also measured. The synthetic wastewater had the viable count of $2.8 \times 10^{3} \mathrm{cfu} / \mathrm{ml}$ and total coliform of $270 \mathrm{cfu} / \mathrm{ml}$. After treatment, the viable count was less than $15 \mathrm{cfu} / \mathrm{ml}$ in both systems. $100 \%$ removals of total coliforms were also observed in treated effluent samples of SMBR and SMABR systems.

Table 2 Total viable counts and total coliform counts at different periods of operation

\subsection{Comparison of critical flux}

Critical flux experiments were carried out after 20-day operation of SMBR and SMABR systems to examine the membrane fouling. The membrane was physical cleaned by using backwash and the cake layer formed by activated sludge was brush off before starting the critical flux experiment. After each 40 minute-flux-step, 1 minutebackwash was provided at a backwash rate of $30 \mathrm{~L} / \mathrm{m}^{2} . \mathrm{h}$ using membrane filtrate. The purpose of backwash was mainly to minimize the TMP increase due to reversible fouling during every experimental flux-step, which could lead to TMP development. Figs. 5 and 6 show the critical flux of SMBR and SMABR systems. According to the 
figures, both of the systems had the same critical flux value of $20 \mathrm{~L} / \mathrm{m}^{2} . h$. However, the TMP value of the SMBR system was much higher than that of the SMABR systems, which were 33 and $7.5 \mathrm{kPa}$ respectively at a filtration flux of $20 \mathrm{~L} / \mathrm{m}^{2} . \mathrm{h}$. This indicated that PAC can reduce membrane fouling. During the cycle test, it was observed that the TMP values obtained during the descending (filtration flux) phase were greater than the corresponding values recorded during the ascending phase. Especially for SMABR system, the TMP values were nearly three folds of the ascending (filtration flux) phase values. For example, at the critical flux-step of $20 \mathrm{~L} / \mathrm{m}^{2}$.h, TMP were 7.5 and $21 \mathrm{kPa}$ for the ascending and descending phases, respectively. These observations indicated that SMABR system formed an initial irreversible fouling due to small PAC particles when the filtration flux was higher than critical flux. The formation of some reversible fouling led to less TMP developments of the SMBR system in the descending phases when compared to SMABR.

Fig. 5. Constant filtration flux vs. TMP of SMBR system

Fig. 6. Constant filtration flux vs. TMP of SMABR system

\section{Conclusions}

SMBR and SMABR systems were compared based on different membrane performance during 20 days operation. It was demonstrated that SMABR system had better performance than SMBR system. PAC addition could mitigate the membrane fouling and led to less TMP development in SMABR system. After acclimatization, the SMABR showed more stable OUR (over 94\%) than that of SMBR system. Adsorption of bacteria on to PAC particles presented higher growth in terms of total viable counts in SMABR system. Nearly $100 \%$ of bacteria in terms of viable count were removed in 
both the systems and $100 \%$ removals of total coliforms were also observed in treated effluent. Both systems showed the same critical flux of $20 \mathrm{~L} / \mathrm{m}^{2} \cdot \mathrm{h}$ after 20 days running except that the SMBR had higher TMP value to maintain the sustainable flux.

\section{Acknowledgment}

This research was funded by DEST International Science Linkages Competitive Grant.

\section{References}

Clark, M. M., Heneghan, K. S., 1991. Ultrafiltration of lake water for potable water production. Desalination 80(2-3), 243-249.

Field, R.W., Wu, D., Howell, J. A., Gupta, B. B., 1995. Critical flux concept for microfiltration fouling. Journal of Membrane Science 100, 259-272.

Guo, W. S., Shim W. G.., Vigneswaran, S. and Ngo, H. H, 2005. Effect of operating parameters in a submerged membrane adsorption hybrid system: mathematical modelling and experiments. Journal of Membrane Science 247, 65-74.

Guo, W. S., Vigneswaran, S. and Ngo, H. H., 2005. Effect of flocculation and/or adsorption as pretreatment on the critical flux of crossflow microfiltration. Desalination 172(1), 53-62.

Kim, H. S., Katayama, H., Takizawa, S., Ohgaki, S., 2001. Removal of coliphage Q $\beta$ and organic matter from synthetic secondary effluent by powdered activated carbonmicrofiltration (PAC-MF) process. Proceedings of IWA Specialized Conference on Membrane Technology, Israel, 211-219. 
Le Clech, P., Jefferson, B., Chang, I. S., Judd, S. J., 2003. Critical flux determination by the flux-step method in a submerged membrane bioreactor. Journal of Membrane Science 227, 81-93.

Lee, J. C., Kim, J. S., Kang, I. J., Cho, M. H., Park, P. K., Lee, C. H., 2001. Potential and limitations of alum or zeolite addition to improve the performance of a submerged membrane bioreactor. Water Science and Technology 43(11), 59-66.

Lee, W., Kang, S., Shin, H., 2003. Sludge characteristics and their contribution to microfiltration in submerged membrane bioreactors. Journal of Membrane Science $216,217-227$.

Pirbazari, M., Voice, T. C., Weber Jr., W. J., 1990. Evaluation of biofilm development on various natural and synthetic media. Hazardous Waste and Hazardous Materials 7 (3), 239-250.

Pitter, P., Chudoba, J., 1990. Biodegradability of organic substances in the aquatic environment. CRC Press, Boca Raton.

Rodde-Pellegrin, M-L., Wisniewski, C., Grasmick, A., Tazi-pain, A., Buisson, H., 2002. Respirometric needs of heterotrophic populations developed in an immersed membrane bioreactor working in sequenced aeration. Biochemical Engineering 11, $2-12$.

Tsai, H. H., Ravindran, V., Pirbazari, M., 2005. Model for predicting the performance of membrane bioadsorber reactor process in water treatment applications. Chemical Engineering Science 60, 5620-5636.

Yamamoto, K., Hiasa, M., Mahmood, T., Matsuo, T., 1989. Direct solid-liquid separation using hollow fiber membrane in an activated sludge aeration tank. Water Science and Technology 21(4-5), 43-54. 
Ying, W., Weber Jr., W. J., 1979. Bio-physicochemical adsorption model systems for wastewater treatment. Water Pollution Control Federation Journal 51 (11), 26612677. 
Table 1

Constituents of the Synthetic Wastewater

\begin{tabular}{lcc}
\hline Compounds & $\begin{array}{c}\text { Molecular weight } \\
(\mathrm{g} / \mathrm{mol})\end{array}$ & $\begin{array}{c}\text { Concentration } \\
(\mathrm{mg} / \mathrm{L})\end{array}$ \\
\hline Organics and nutrients & & \\
Glucose $\left(\mathrm{C}_{6} \mathrm{H}_{12} \mathrm{O}_{6}\right)$ & 180.0 & 280 \\
Ammonium sulfate $\left(\left(\mathrm{NH}_{4}\right)_{2} \mathrm{SO}_{4}\right)$ & 132.1 & 72 \\
Potassium phosphate $\left(\mathrm{KH}_{2} \mathrm{PO}_{4}\right)$ & 136.1 & 13.2 \\
Trace nutrients & & \\
Calcium chloride $\left(\mathrm{CaCl}_{2} \cdot 2 \mathrm{H}_{2} \mathrm{O}\right)$ & 147.0 & 0.368 \\
Magnesium sulfate $\left(\mathrm{MgSO}_{4} \cdot 7 \mathrm{H}_{2} \mathrm{O}\right)$ & 246.5 & 5.07 \\
Manganese chloride $\left(\mathrm{MnCl}_{2} \cdot 4 \mathrm{H}_{2} \mathrm{O}\right)$ & 197.9 & 0.275 \\
Zinc sulfate $\left(\mathrm{ZnSO} \cdot 7 \mathrm{H}_{2} \mathrm{O}\right)$ & 287.5 & 0.44 \\
Ferric chloride anhydrous $\left(\mathrm{FeCl}_{3}\right)$ & 162.2 & 1.45 \\
Cupric sulfate $\left(\mathrm{CuSO}_{4} \cdot 5 \mathrm{H}_{2} \mathrm{O}\right)$ & 249.7 & 0.391 \\
Cobalt chloride $\left(\mathrm{CoCl}_{2} \cdot 6 \mathrm{H}_{2} \mathrm{O}\right)$ & 237.9 & 0.42 \\
Sodium molybdate dihydrate $\left(\mathrm{Na}_{2} \mathrm{MoO}_{4} \cdot 2 \mathrm{H}_{2} \mathrm{O}\right)$ & 242.0 & 1.26 \\
Yeast extract & & 30 \\
\hline
\end{tabular}


Table 2

Total viable counts and total coliform counts at different periods of operation

\begin{tabular}{cccc}
\hline Day & System & Total Count, cfu/mL & Total Coliforms, cfu/mL \\
\hline \multirow{2}{*}{0} & SMBR & $1.6 \times 10^{2}$ & 90 \\
& SMABR & $3.5 \times 10^{2}$ & 35 \\
\hline \multirow{2}{*}{10} & SMBR & $6.5 \times 10^{2}$ & 38 \\
& SMABR & $1.6 \times 10^{4}$ & 43 \\
\hline \multirow{2}{*}{15} & SMBR & $6 \times 10^{2}$ & 30 \\
& SMABR & $2.24 \times 10^{4}$ & 23 \\
\hline
\end{tabular}

Samples were taken from the middle part of the reactor 


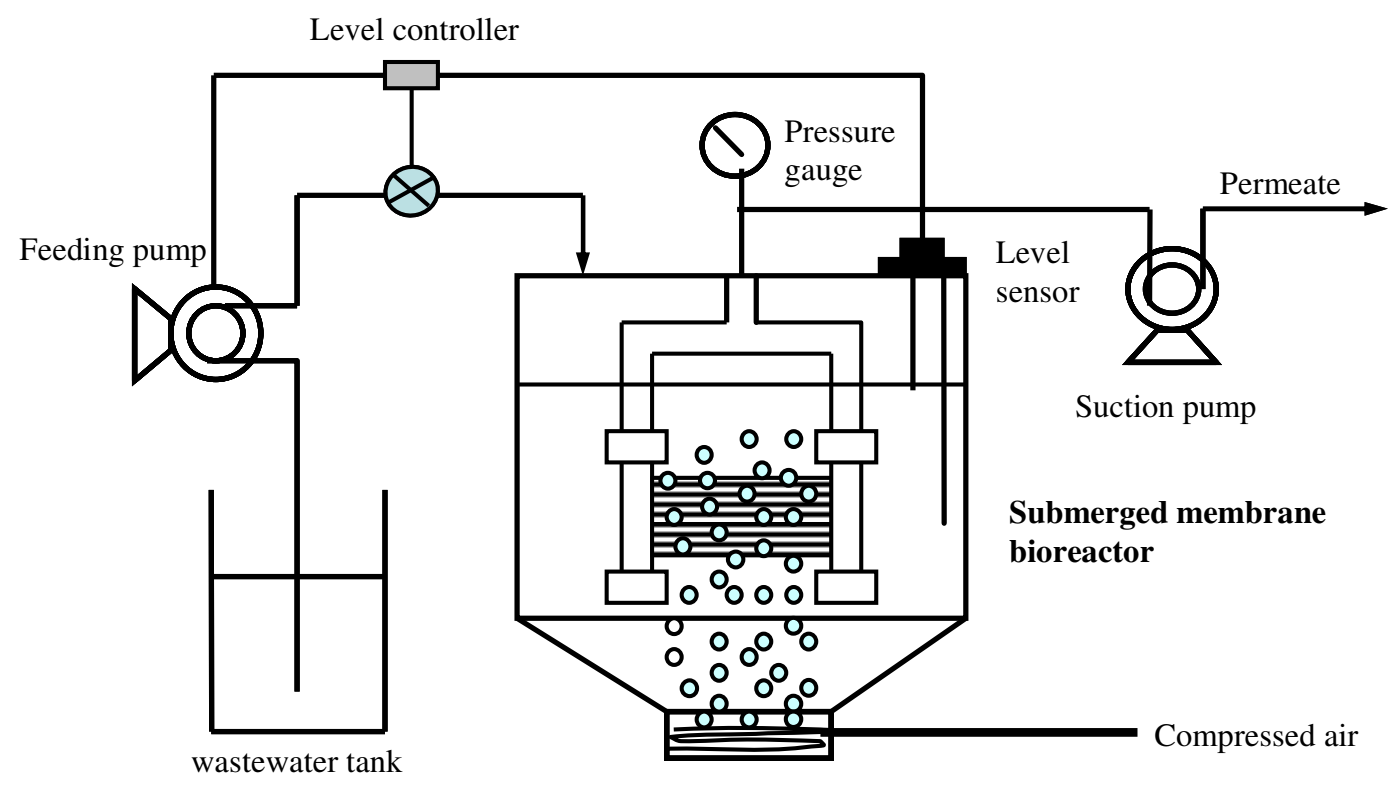

Fig. 1. Experimental set-up of SMBR 


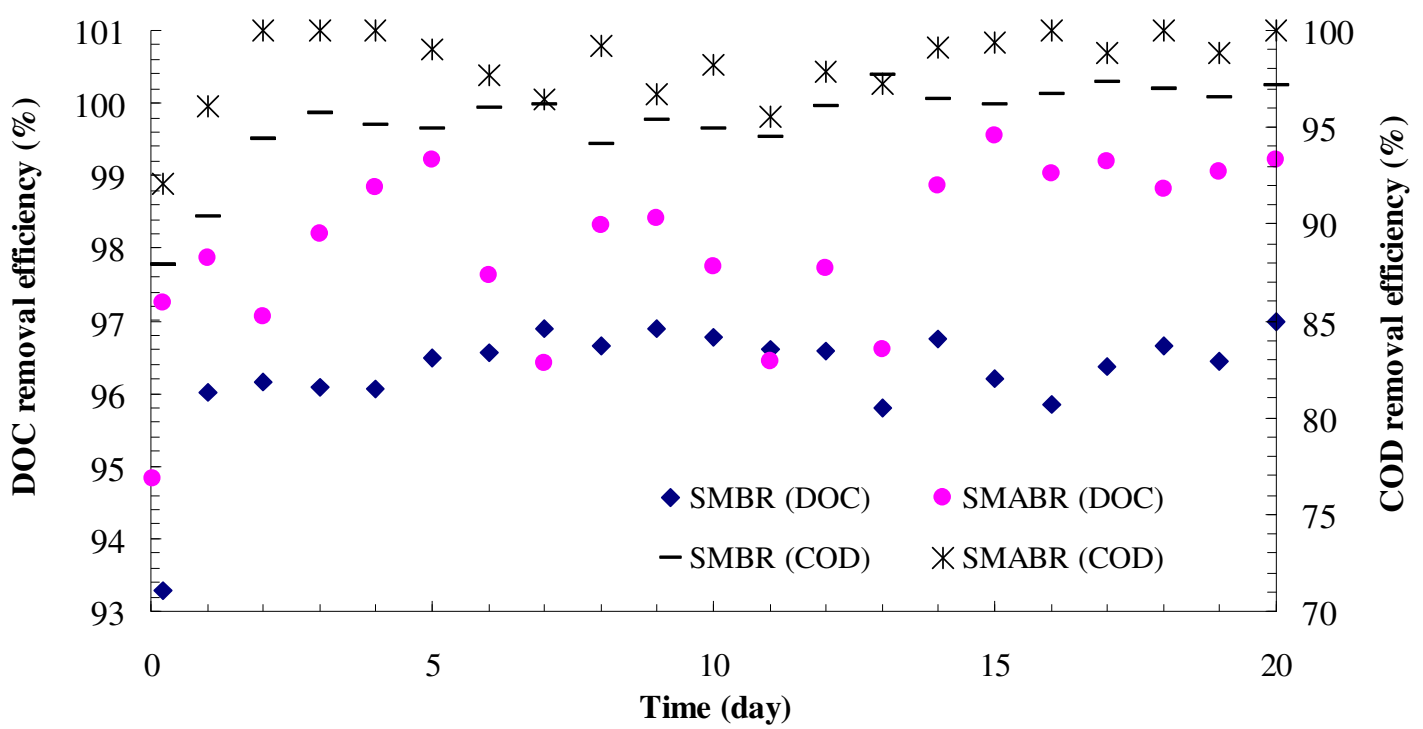

Fig. 2. DOC and COD profile of SMBR and SMABR systems (filtration flux $=10 \mathrm{~L} / \mathrm{m}^{2} . \mathrm{h}$; PAC dose $=5 \mathrm{~g} / \mathrm{L} ;$ backwash rate $=30 \mathrm{~L} / \mathrm{m}^{2} . \mathrm{h} ;$ backwash $=1$ minute every 1 hour; HRT $=3.1)$ 


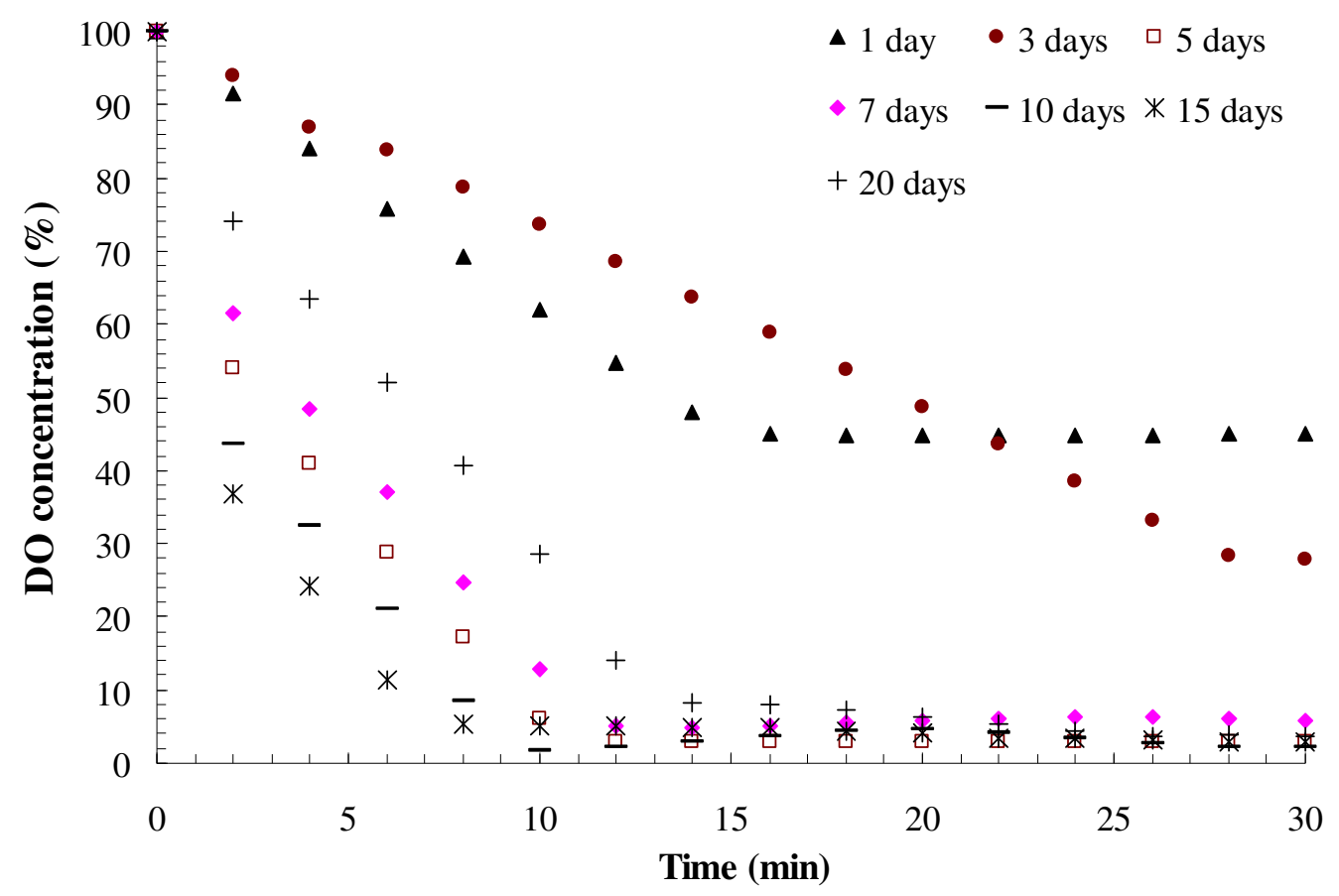

Fig. 3. OUR variation of the mixed liquor in SMBR system 


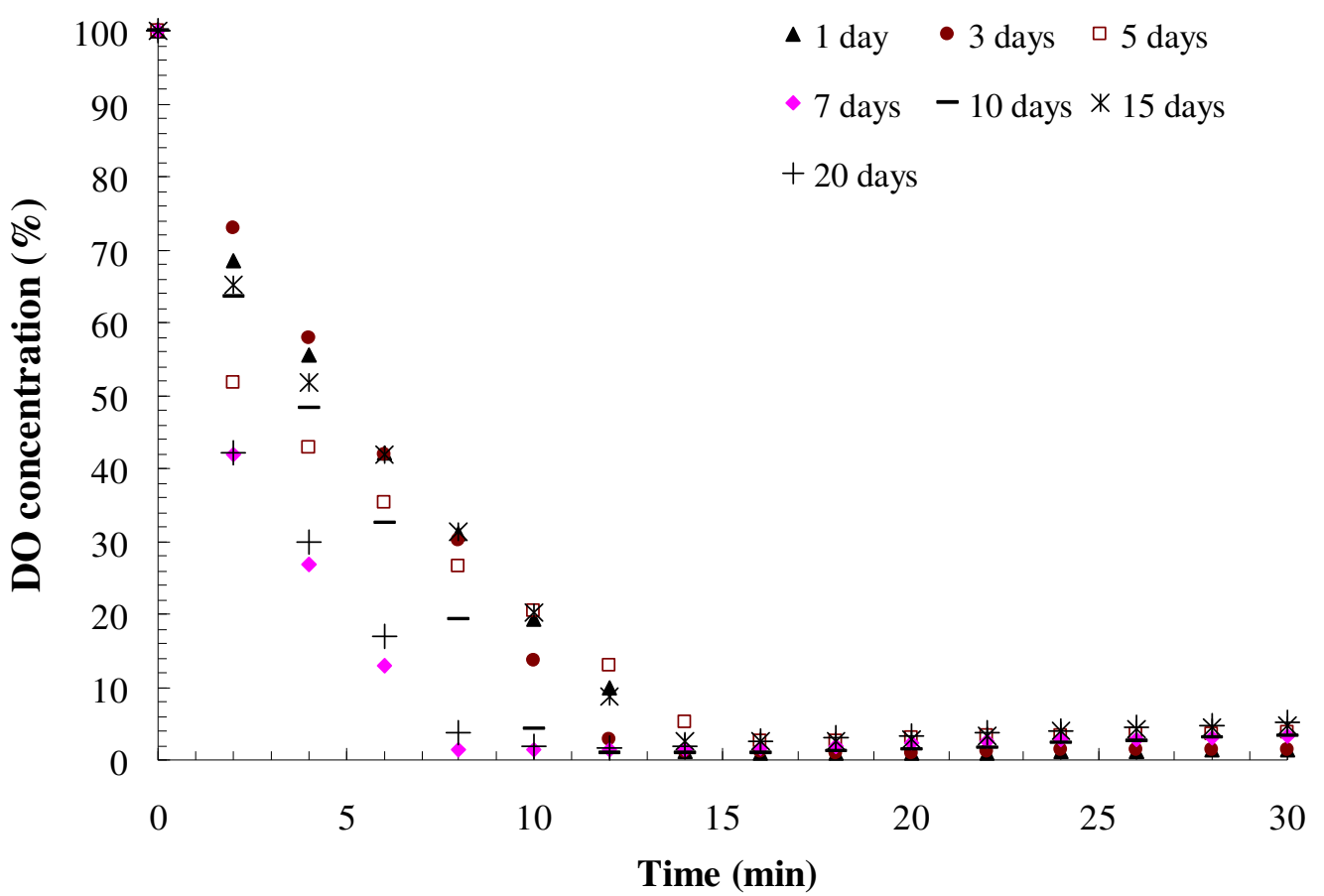

Fig. 4. OUR variation of the mixed liquor in SMABR system 


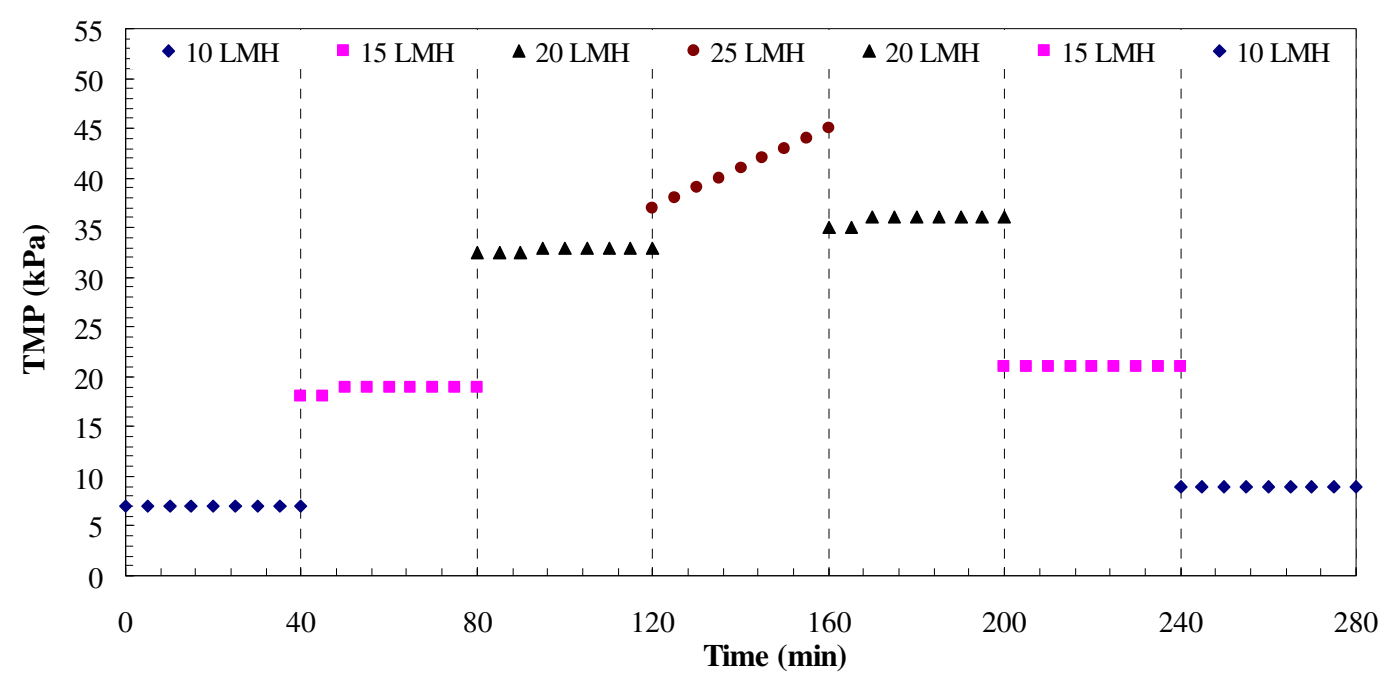

Fig. 5. Constant filtration flux vs. TMP of SMBR system $\left(\mathrm{LMH}=\mathrm{L} / \mathrm{m}^{2} . \mathrm{h}\right)$ 


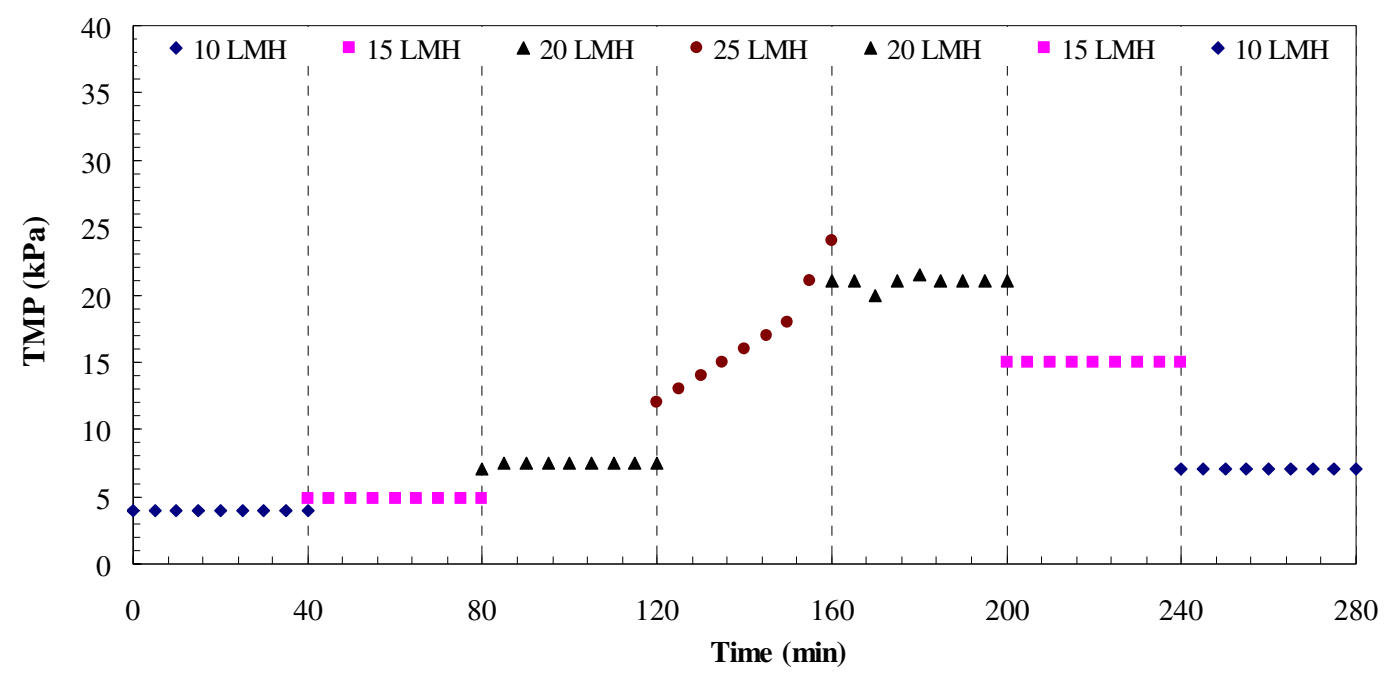

Fig. 6. Constant filtration flux vs. TMP of SMABR system $\left(\mathrm{LMH}=\mathrm{L} / \mathrm{m}^{2} . \mathrm{h}\right)$ 